ENCYCLOPEDDIE Encyclopédie berbère

BERBERE

15 | 1995

15 | Daphnitae - Djado

\title{
Daradae / Darat(h)itae
}

\section{J. Desanges}

\section{OpenEdition}

Journals

Édition électronique

URL : http://journals.openedition.org/encyclopedieberbere/2217

DOI : 10.4000/encyclopedieberbere. 2217

ISSN : 2262-7197

\section{Éditeur}

Peeters Publishers

\section{Édition imprimée}

Date de publication : 1 avril 1995

Pagination : 2230

ISBN : 2-85744-808-2

ISSN : 1015-7344

\section{Référence électronique}

J. Desanges, «Daradae / Darat(h)itae », Encyclopédie berbère [En ligne], 15 | 1995, document D16, mis en ligne le 01 juin 2011, consulté le 24 septembre 2020. URL : http://journals.openedition.org/ encyclopedieberbere/2217 ; DOI : https://doi.org/10.4000/encyclopedieberbere.2217

Ce document a été généré automatiquement le 24 septembre 2020

(c) Tous droits réservés 


\section{Daradae / Darat(h)itae}

\section{J. Desanges}

1 Pline l'Ancien $(\mathrm{V}, 10)$, d'après la relation du périple de Polybe, situe sur le rivage de l'Atlantique, après les Ethiopiens Perorsi* pour qui vient du détroit de Gadès (détroit de Gibraltar), des Ethiopiens Darathitae (ou Daratitae). Leur nom étant formé sur celui du Dara $(\mathrm{t})^{*}$ (oued Draa), ils devaient être établis au voisinage de l'embouchure de ce fleuve. Ptolémée (IV, 6, 5, Müller, p. 743-744) mentionne, parmi les très grands peuples qui habitent la Libye déserte, celui des Daradae qui occupe «les abords maritimes du fleuve homonyme ». Il les cite encore (IV, 6, 6, p. 745) comme des voisins des Mandori*, dont le nom peut être rapproché de celui du Mont Mandron (ibid. et IV, 6, 3, p. 735). Il en fait enfin état (IV, 7, 10, p. 785), de façon beaucoup plus vague, à partir de l'Ethiopie subégyptienne, loin vers l'ouest par delà un désert de sables arides, et après les Trallētae*. On remarquera que les Perorsi et les Daradae de Pline l'Ancien, qualifiés d'Ethiopiens les uns et les autres, sont des riverains de la mer, alors que les Pharusii* et les Gétules Darae* sont situés par le Naturaliste à l'intérieur des terres.

\section{INDEX}

Mots-clés : Antiquité, Gétules, Tribu 